\title{
Comment
}

\section{The English Sweating Sickness, 1485-1551: A Viral Pulmonary Disease?}

\author{
MARK TAVINER, GUY THWAITES, VANYA GANT*
}

A recent article in this journal describes an analysis of the 1551 outbreak of the sweating sickness. ${ }^{1}$ Dr Dyer's research, based on 680 extant parish registers, represents to date the most comprehensive and detailed analysis of the demographic impact of any of the five outbreaks of the sweating sickness of 1485, 1508, 1517, 1528 and 1551. Furthermore, his article supersedes previous analyses of the demographic impact of the sweating sickness based on either parish registers ${ }^{2}$ or testamentary evidence. ${ }^{3}$ Contemporary impressions of strong age, class, and sex predispositions of the victims of the sweating sickness to young, rich males are modified to give a more dispassionate and informed picture. He also shows how the sweating sickness was predominantly a rural rather than an urban disease, with a limited overall demographic impact, and that there may have been occurrences outside the five "classic" epidemic years. 4

This extensive demographic material is then used to provide a fuller epidemiological explanation for the aetiology of the sweating sickness. The underlying hypothesis is that the causative agent of the sweating sickness was spread by human-to-human contact as well as initially through a zoonosis or an environmental vector. This suggestion of humanto-human transmission stems from two aspects of the register data: first, the observable sequences of gender biases and intra-familial trends of mortalities at a parish level, and secondly from the spread of the epidemic at a national level.

Dyer shows that when London was affected in the early weeks of July there was a distinct male preponderance of victims, although the total number of deaths was not strikingly high. This male preponderance was not always paralleled outside the capital, however; Dyer observes that in rural parishes mortalities due to the sweating sickness

* Mark Taviner, MA (Cantab), MPhil, Department of Modern History, St Andrews University, St Andrews, KY16 9AL; Guy Thwaites, MA (Cantab), MB, BS, Guy's and St Thomas' NHS Trust, London SE1 7EH; Vanya Gant, MRCP, MRCPath, Division of Clinical Laboratory Sciences, 5th Floor North Wing, St Thomas's Hospital, UMDS, London SE1 7EH.

\footnotetext{
1 A Dyer, 'The English sweating sickness of 1551: an epidemic anatomized', Med. Hist., 1997, 41: 362-84.

2 J A H Wylie, I J Linn, R Helps, 'The changing face of the English sweating sickness in the epidemic
}

of August 1551, in Devonshire. A shift towards endemicity?', Reports and Transactions of the Devonshire Association for the Advancement of Science, Literature and Art, 1984, 116: 97-107; E A Wrigley and R S Schofield, The population history of England, 1541-1871: a reconstruction, London, Edward Arnold, 1981, p. 670.

${ }^{3}$ R S Gottfried, 'Population, plague and the sweating sickness: demographic movements in late fifteenth-century England', J. Br. Stud., 1977, 17: 12-37.

${ }^{4}$ Dyer, op. cit., note 1 above, passim. 


\section{The English Sweating Sickness, 1485-1551}

were often "long runs of burials dominated by one sex or the other". These patterns of gender bias lead him to conclude that "in the absence of any direct information, the sweating sickness was not generally transmitted by an insect vector but rather through close personal contact." Furthermore, Dyer sees the spread of the epidemic at a national level as following lines of communication and human contact; "The national epidemic displays a disease capable of very rapid movement at certain times, consistent with distribution by travellers." 5

The summer preponderance and scattered rural nature of the sweating sickness leads Dyer to concur with Wylie and Collier's suggestion that an arthropod-borne virus with a rodent host (arbovirus) was the causative agent of the sweating sickness. ${ }^{6}$ However, Dyer distinguishes between two apparent means of transmission of the disease during the early and later stages of the 1551 outbreak: "very rapid transmission by travellers along the road system is clearly the agency by which the sweat epidemic of 1551 was spread from June onwards, although this may not have been the case in the spring." This presents us with aetiological difficulties since arboviruses are only ever transmitted via an arthropod vector-never by human-to-human transmission.

We believe that it is possible to refine an hypothesis for an aetiological agent by once again returning to contemporary descriptions of the clinical features of the sweating sickness. In particular, two treatises on the sweating sickness by the contemporary physicians Thomas Forestier ${ }^{7}$ and John Caius ${ }^{8}$ may be constructively interpreted to provide valuable descriptions of clinical features within a modern framework. Caius describes the six "signes or tokens" by which the sweating sickness might be recognized: he portrays a typical viral prodrome of myalgia and headache, progressing to abdominal pain, vomiting, increased headache and delirium, followed by cardiac palpitation, possible paralysis with agonal breathlessness, and then possible death, usually within 12 to 24 hours of the onset of symptoms. ${ }^{9}$ One of the differences Caius recognized between the sweating sickness and the plague was the absence of the "buboes" and other cutaneous signs. It is this very absence of exanthematous or haemorrhagic signs which casts further doubt on an arboviral agent, generally characterized by these cutaneous signs; nor do arboviruses display the rapidity of clinical course so characteristic of the sweating sickness. Some sources, however, place an emphasis on the breathlessness of the sweating sickness victims. Forestier, in his chapter 'On the signs of the pestilent fever', describes how the "exterior" was relatively calm compared to the "excited interior", and continues, "but it is on account of the ill-natured, fetid, corrupt, putrid and loathsome vapours close to the region of the heart and of the lungs, whereby they grow ill, and the panting of the breath itself magnifies and increases and restricts: because of the external heat and fire itself near the heart." 10

\footnotetext{
${ }^{5}$ Dyer, op. cit., note 1 above, pp. 376, 382.

6 J A H Wylie and L H Collier, 'The English sweating sickness (sudor anglicus): a reappraisal', J. Hist. Med., 1981, 36: 425-45.

7 T Forestier, Tractatus contra pestilentiam thenasmonem et dissinteriam, Rouen, 1490.

$8 \mathrm{~J}$ Caius, $A$ boke, or counseill against the disease commonly called the sweate or sweating sicknesse, London, 1552.

${ }^{9}$ Caius, ibid., p. 8.
}

\footnotetext{
${ }^{10}$ Forestier, op. cit., note 7 above, sig. avii ${ }^{\mathrm{v}}$. One further source as yet unexplored is the pamphlet literature occasioned by the spread of the sweating sickness to the continent in 1529; many of these pamphlets were edited in the nineteenth century by Heinrich Haeser, Scriptores de sudore anglico superstites. Collegit Christianus Gottfridus Gruner, Jena, 1847. Dr Dyer (personal communication) also expresses a hope that this source may yield further information.
} 


\section{Mark Taviner, Guy Thwaites, Vanya Gant}

In a recent article we have also proposed that the sweating sickness's summer preponderance and scattered rural nature suggests a viral infectious agent with a rodent reservoir. ${ }^{11}$ The clinical symptoms described by Caius and other contemporaries, and. especially the marked pulmonary component described by Forestier, have led us to point out the similarities between the clinical features and epidemiological characteristics of the sweating sickness and those of the Hantavirus Pulmonary Syndrome (HPS) which was first recognized in the southwestern United States in May 1993. The syndrome is caused by acquiring a virus normally infecting small rodents, and consists of a brief and nonspecific prodrome of fever, myalgia, headache and rapidly progressive noncardiogenic pulmonary oedema, requiring mechanical ventilation in 88 per cent of patients within 24 hours of admission; ${ }^{12}$ those that died despite ventilation did so within approximately 72 hours. ${ }^{13}$

Dr Dyer's demographic data for the 1551 epidemic complements our proposal that the sweating sickness was a viral disease with a rodent vector. Nevertheless, Dr Dyer's evidence for case-to-case transmission, based on the gender- or family-based runs of mortalities at a parish level, and the rural rather than urban concentration of the epidemic, might equally well be interpreted as reflecting a simultaneous clustering of infected small mammal populations. Infection might have progressed through exposure to peridomestic rodents, as is the case for Hantavirus pulmonary syndrome. ${ }^{14}$ Dr Dyer also discusses the additional evidence for case-to-case transmission, where disease was spread "by travellers along the road system ... from June onwards" and with reports of the "explosive spread of the disease through intra-mural London". ${ }^{15}$ Some very recent reports now demonstrate human case-to-case transmission of hantaviruses, including the pulmonary syndrome variant. ${ }^{16}$ This last observation lends further biological plausibility to our argument that the causative agent for the sweat was a virus with a marked pulmonary component and few cutaneous signs, the epidemiology of which is also now consistent with Dr Dyer's demographic data.

${ }^{11} \mathrm{G}$ Thwaites, M Taviner, V Gant, 'The English sweating sickness 1485-1551', New Engl. J. Med., 1997, 336: 580-2.

12 J S Duchin, F T Koster, C J Peters, et al., 'Hantavirus pulmonary syndrome: a clinical description of 17 patients with a newly recognized syndrome', New Engl. J. Med., 1994, 330: 949-55.

${ }^{13}$ H Levy, S Q Simpson, 'Hantavirus pulmonary syndrome', Am. J. Respir. Crit. Care Med., 1994, 149: $1710-13$.

\footnotetext{
14 A S Khan, R F Khabbaz, L R Armstrong, et al., 'Hantavirus pulmonary syndrome: the first 100 cases', J. infect. Dis., 1996, 173: 1297-303.

${ }^{15}$ Dyer, op. cit., note 1 above, p. 383.

${ }^{16} \mathrm{R}$ Wells, S S Estani, Z E Yado, et al., 'An unusual Hantavirus outbreak in southern Argentina: person-to-person transmission?', Emerging infect. Dis., 1997, 3: 171-4.
} 